\title{
THE INFLUENCE OF EXPERIMENTAL THYROID INTOXI- CATION ON THE POTASSIUM, SODIUM, AND WATER CONTENT OF THE MYOCARDIUM
}

\author{
By EATON M. MACKAY AND H. C. BERGMAN
}

(From the Scripps Metabolic Clinic, La Jolla, Calif.)

(Received for publication December 21, 1931)

Harrison et al. (1) analyzed samples of cardiac and skeletal muscle obtained from patients who had died of congestive heart failure and found them to be abnormally poor in potassium. It is their belief $(2,3)$ that this diminution in the potassium content is related to overwork and the attendant fatigue. The heart in experimental thyrotoxicosis seemed to offer a possible opportunity of examining the hypothesis in question under controlled conditions. In addition, the effect of thyroid intoxication on the potassium content of the greatly enlarged heart has an interest of its own.

Thirty-six male albino rats 140 days old and 14 rats 100 days old were divided into two groups on the basis of body weight. For two weeks they all received a special diet described elsewhere (4). In addition the diet of one group had 0.2 per cent of desiccated thyroid (Wilson Laboratories) intimately mixed with it. At the end of the period the rats were etherized and the heart removed, freed of adherent blood by blotting on filter paper, weighed on an analytical balance, and preserved for analysis. The water content of the tissue was determined by drying to constant weight at $80^{\circ} \mathrm{C}$. in vacuo. The residue was then ashed with the aid of nitric acid and heat. Either sodium or potassium was determined on the ash, the small quantity of sample precluding both determinations upon a single heart. For sodium the modification of the uranyl zinc acetate method described by Butler and Tuthill (5) was used and for potassium the volumetric modification of the chloroplatinate method described by Shohl and Bennett (6). The potassium content was determined in the hearts of 15 animals of each group and the sodium content measured in those of the remainder.

The results have been tabulated in Table I. The administration of thyroid substance, although producing the usual marked increase in the weight of the heart, was without demonstrable effect upon the water, potassium or sodium content of the myocardium.

The data tabulated here give no support to the idea that overwork or fatigue causes a diminution in the potassium content of cardiac muscle insofar as the effect of thyroid substance is concerned. They 


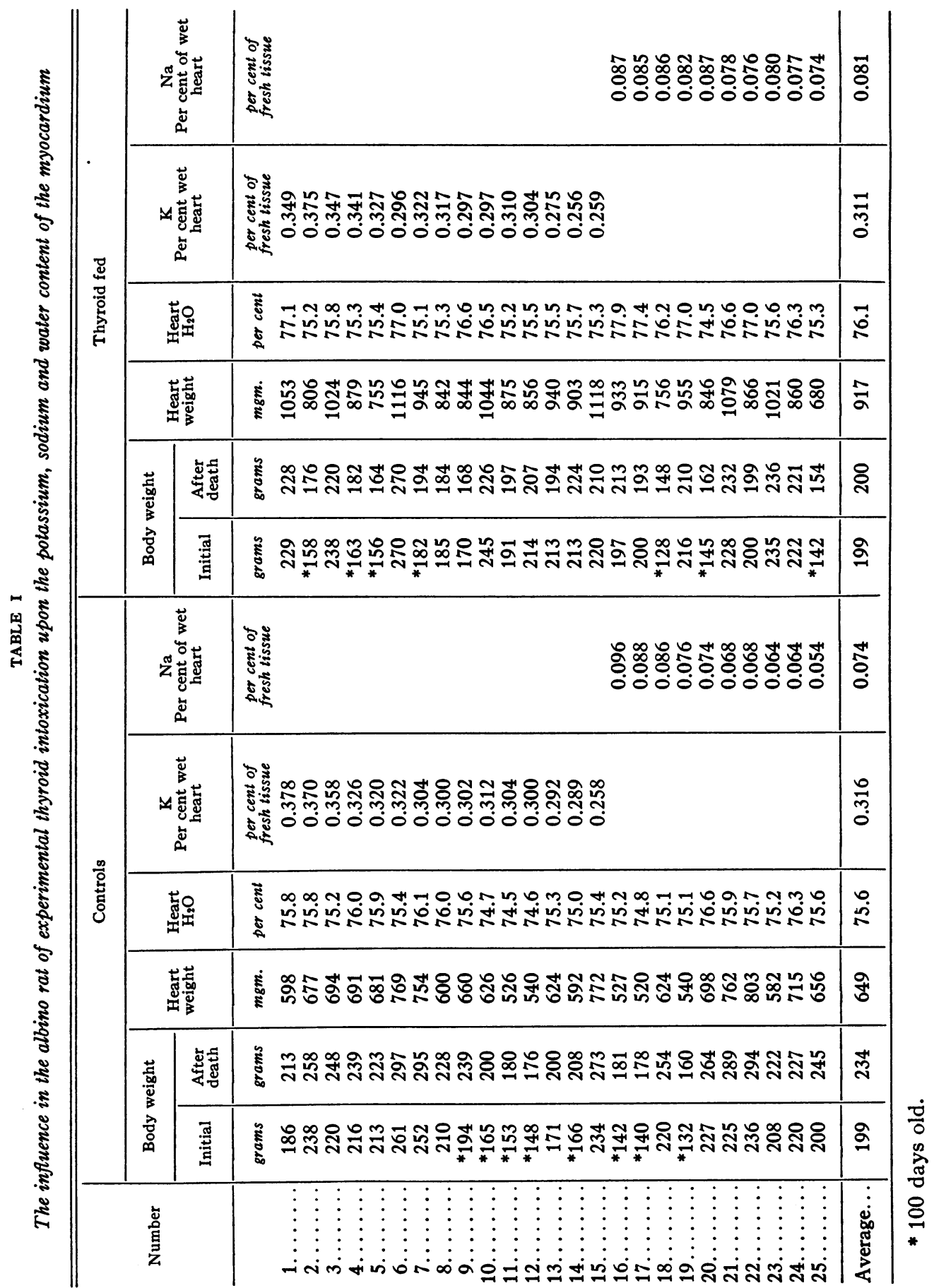


cannot, however, be interpreted as directly opposing this hypothesis proposed by Harrison $(2,3)$, for there is some doubt (7) that heart failure ever occurs in goiter with hyperthyroidism as its sole cause. If this is true our assumption that thyroid intoxication produces overwork and fatigue of the myocardium may be incorrect.

The constancy in the potassium content of the heart muscle before and following thyroxinization is very interesting. It would appear to indicate that the increase in heart weight is a simple hypertrophy, the tissue having essentially the same composition after the remarkable weight increase as before the administration of thyroid material.

\section{SUMMARY}

The increase in heart weight which ensues when active thyroid material is administered to the albino rat is without demonstrable effect upon the potassium, sodium or water content of the myocardium.

\section{BIBLIOGRAPHY}

1. Harrison, T. R., Pilcher, C., and Ewing, G., J. Clin. Invest., 1930, viii, 325. Studies in Congestive Heart Failure. IV. The Potassium Content of Skeletal and Cardiac Muscle.

2. Calhoun, J. A., Cullen, G. E., Clarke, G., and Harrison, T. R., J. Clin. Invest., 1930, ix, 393. Studies in Congestive Heart Failure. VI. The Effect of Overwork and Other Factors on the Potassium Content of the Cardiac Muscle.

3. Calhoun, J. A., and Harrison, T. R., J. Clin. Invest., 1931, x, 139. Studies in Congestive Heart Failure. IX. The Effect of Digitalis on the Potassium Content of the Cardiac Muscle of Dogs.

4. MacKay, E. M., and MacKay, L. L., J. Exp. Med., 1926, xliii, 395 . Compensatory Hypertrophy of the Adrenal Cortex.

5. Butler, A. M., and Tuthill, E., J. Biol. Chem., 1931, xciii, 171. An Application of the Uranyl Zinc Acetate Method for Determination of Sodium in Biological Material.

6. Shohl, A. T., and Bennett, H. B., J. Biol. Chem., 1928, lxxviii, 643. A Micro Method for the Determination of Potassium as Iodoplatinate.

7. McEachern, D., and Rake, G., Johns Hopkins Hosp. Bull., 1931, xlviii, 273. A Study of the Morbid Anatomy of Hearts from Patients Dying with Hyperthyroidism. 